\title{
Oppikirja arvioinnin etiikasta painottaa yksilön näkökulmaa
}

Päivi Atjonen (2007). Hyvä, paha arviointi. Tammi. 256 sivua.

$\mathrm{K}_{\mathrm{a}}$ Päivi Atjosen teos Hyvä, paha arviointi on ajankohtainen ja tärkeä kirja. Monien yhteiskunnallisten muutosten seurauksena arvioinnista on tullut laaja kysymys, eikä se enää koske yksinomaan koulutusjärjestelmää. Juuri tästä syystä oli tärkeää, että aiheesta kirjoitetaan oppikirja. Atjosen kirja ei kuitenkaan ole vain arviointikäytäntöihin liittyä oppikirja vaan aivan liian vähälle jätetyn arvioinnin etiikan teeman kattava ja opettavainen koonti.

Teos koostuu seitsemästä luvusta, joissa etiikan yleisestä luonnehdinnasta siirrytään sujuvasti erilaisten arviointikäytäntöjen arvioinnin kautta yhteiskunnallisten sidoksia ja valtaasetelmia tarkastellen arvioitsijan hyveiden määrittelyyn. Teoksen lukujen kautta lukija saa perustiedot erilaisesta etiikan käsitystavoista ja Atjonen osoittaa myös, kuinka ne voidaan perustellusti liittää osaksi arvioinnin käytäntöjä.

Kirjan avaa luku Arviointi ja etiikka - käsitteitä ja käytäntöjä, missä Atjonen avaa etiikka- käsitteen sekä arvioinnin käsitteen määrittelyjä. Atjonen osoittaa kiinnostavalla tavalla, kuinka etiikka ja arviointi jo lähtökohdallisesti kietoutuvat yhteen. Teemaa käsitellessään Atjonen tarjoaa alustavan kuvauksen arviointikäytäntöjen muutoksesta ulkoisesta arvioinnista sisäiseen arviointiin, joissa arvioinnin kohteena olevat tahot ovat samalla siirtyneet ulkopuolisesta roolistaan osallisen rooliin. Juuri tämä muutos tekee etiikan pohdinnan arviointitoiminnassa Atjosen mukaan niin keskeiseksi.

Toinen luku käsittelee eettisesti kestävän arvioinnin ominaispiirteitä ja periaatteita. Siinä Atjonen erittelee eettisesti hyvän arvioinnin keskeisiä arvoja ja periaatteita sekä pyrkii kumoamaan arviointiin liittyviä virheellisiä myyttejä. Luvun keskeisen sanoman, monien kiinnostavien yksityiskohtien välisen sidoksen voisi tiivistää siihen, että hyvän ja eettisesti kestävän arvioinnin estävät erityisesti moninaiset asenteet. Erityisesti tämä kiteytyy Atjosen mukaan asenteessa erilaisia arvioitsijoita kohtaan. Useinhan ajattelemme, että mitä tämä arviointia suorittava asiantuntija voi tietää enemmän esimerkiksi työstäni tai sen ongelmista, minähän työtäni teen ja näitä ongelmia koen.

Yleisten teoreettisten kysymysten ja linjausten jälkeen Atjonen lähestyy seuraavassa luvussa arvioinnin etiikkaa koskien oppimisen ja sen ohjaamisen arviointieettisiä kysymyksiä. Atjonen käsittelee erilaisten filosofisten ihmiskäsityksen kautta oppimisen arviointia koskevia lähestymistapoja. Arvioinnin tarkoituksena hän näkee tukea oppimista.

Kiinnostava listaus luvun lopussa koskee pahan arvioinnin tunnuspiirteistöä. Tätä listausta olisi voinut avata enemmän ai- kalaiskriittisen arvioinnin suuntaan ja samalla pohtien kysymystä erityisten ja yleisten vaatimusten ja tavoitteiden välisistä suhteista.

Neljännessä luvussa Atjosta kiinnostaa jo edellisessä luvussa esille noussut osallistuvan arvioinnin eettinen perusta. Atjosen mukaan monipuolinen, vastavuoroinen, voimauttava ja tunnustusta tarjoava sekä vastuuta ja autonomisuutta tukeva arviointi, joka edellisessä luvussa kuvattiin konstruktivistisen oppimiskäsityksen valossa, vaatii juuri arvioitavan osallisuutta arviointiprosessissa. Kuten Atjonen kirjoittaa, arvioitavalla on siis tietynlainen omistajuus arviointiin (s. 99). Atjonen kuvaa luvussa eräänlaisen kumppanuusperiaatteen, joka takaa luottamuksen ilmapiirin arviointitilanteessa, kun sitä tarkastellaan sisäisenä arviointina. Tämä luottamus on omiaan turvaamaan hänen mukaansa moniäänisyyttä ja viimekädessä turvaa huonommassa osassa olevien etuja.

Viides luku käsittelee ulkoisen arvioinnin oikeutusta. Atjosen mukaan ulkoinen arviointi voi saavuttaa parhaimmillaan puolueettoman ja riippumattoman aseman. Jos arvioitava tilanne on erittäin ongelmallinen, kätkeytyy ulkoisen arvioinnin puolueettomuuteen lupaus siitä, että esimerkiksi ihmiset olisivat juuri puolueettomuuden nojalla motivoituneita soveltamaan arvioinnin kautta saavutettuja toimenpide- ym. ehdotuksia. Tietenkin tähän kaikkeen jatkuvaan arviointiin saattaa Atjosen mukaan 
sisältyä vaara, että päädytään arvioitavien esineellistämiseen. Atjonen kirjoittaa: ”Teknologisessa ja hallinnollisessa edistymispyrkimyksessään moderni maailma menettää näyn moraalisesta ja inhimillisestä tarpeesta, jota sen pitäisi palvella. Tehokkuus ensisijaiseksi arvoksi kohotettuna alkaa vähätellä inhimillisiä huolenaiheita. Yksilöitä kohdellaan välineinä tavoitteen saavuttamisessa, ja tavoitteita suurempi hyöty, alemmat tuotantokustannukset ja tuotannon nopeuttaminen.” Onko tämän ajankohtaisempaa huolta!

Edellisen vaaran välttämiseksi Atjonen keskittyy luvussa Vallankäytöstä huolenpitoon: arvioinnin kahdet eettiset kasvot käsittelemään vallan ja vaikutusvallan problematiikkaa. Tähän lukuun olisi tuonut erittäin tärkeän panoksen Erich Fromm, koska hänen kasvatustoimintaan liittyvät huomiot keskittyivät muun muassa erilaisten valtasuhteiden erittelyyn ${ }^{1}$. Atjonen kuitenkin lähestyy kysymystä toisin ja painottaa yksilön kykyä hyödyntää arviointityössä olevia valta-asetelmia joko taitavasti tai taitamattomasti. Taitavasti käytettynä ne voivat tukea yhteisöllisyyttä. Tällöin arvioitsija kantaa huolta arvioitavien hyvinvoinnista auttaa heitä kasvuun, itsensä toteuttamiseen ja itseohjautuvuuteen. Atjonen asettaa kasvun, itsensä toteuttamisen ja itseohjautuvuuden tavoitteet arvioinnin keskeisiksi päämääriksi.

\section{K} ta voi hyvin päätellä, päätyy Atjonen seitsemännessä luvussa käsittelemään arvioijan keskeisiä hyveitä aristotelisen hyveetiikan pohjalta. Koko ajatus hyveellisestä arvioitsijasta huutaa rinnalleen pohdintaa itsekasvatuksesta. Jos ihmiset kasvavat jo varhain tiettyyn yhteiskuntaan ja sen mukana tiettyihin toimintaodotuksiin ja -rooleihin(siis yhteiskunnallistuvat - Vergesellschaftlichung kuten Ernst Simmel kirjoitti), niin millä edellytyksillä ihminen voisi kasvaa esimerkiksi parempaan ihmisyyteen tai hyveellisyyteen myöhemmin? Aristoteles varmasti vastaisi, ettei tätä mahdollisuutta ole enää sen jälkeen, kun tietyt luonteenpiirteet on saavutettu. Sinä joko olet tai et ole esimerkiksi suurisieluinen. Tässä mielessä Aristoteleen kohtalaisen staattisen eettisen kosmologian nostaminen tässä yhteydessä on hieman ontuvaa, koska arvioinnissa on kuitenkin lopulta kysymys yksittäisten ihmisten sopeutumisesta tiettyihin heille ulkoisiin vaatimuksiin. Edellisestäkin huolimatta Atjonen kuitenkin rohkenee esittää arvioijan hyveet: autonomia, suhteessa olon kyky ja itsensä ylittämisen kyky.

Kirjan päättävässä luvussa Kohti eettisesti kestävää arviointia Atjonen kokoaa esittämiään teemoista eräänlaisen ohjelmallisen hahmotelman huolenpidon ja oikeudenmukaisuuden etiikan näkökulmasta, jossa pai- nottuu yksilön näkökulma.

Kaiken kaikkiaan Päivi Atjosen esittämät näkökannat arviointiin liittyvistä kysymyksistä ovat tärkeitä ja niistä tulisi keskustella aktiivisesti myös yleisiä kulttuurisina teemoina. Paikoitellen olisin toivonut yksilöä painottavan näkökulman rinnalle yhteiskunnan kehityskulkuja avaavaa ja erittelevää asetelmaa. Tällainen näkökulma olisi avautunut esimerkiksi Frankfurtin koulun kriittisestä teoriasta ponnistavan kasvatusteorian avul$1 \mathrm{a}^{2}$.

Teos on selkeästi kirjoitettu ja tekstin lomaan on ripoteltu pohdintaa edistäviä teemoja ja kysymyksiä. Suosittelenkin kirjaa lämpimästi oppikirjaksi ja ajattelun herättelijäksi kaikille arviointia opiskeleville, arvioinnista kiinnostuneille ja arviointityötä tekeville ihmisille.

\section{Viitteet}

1. Ks. Esim. Päivi Moisio (1999). Kasvattamisen vaikea taito. Teoksessa Olli-Pekka Mosio, Kritiikin lupaus. Jyväskylä: SoPhi.

2. Tästä hyvänä esimerkkinä vaikkapa Stephen Brookfield teoksillaan Critically Reflective Teacher (1995) ja Power of Critical Theory (2005).

\section{Olli-Pekka Moisio}

